(Житомирський національний агроекологічний університет)

\title{
РОЗВИТОК ПРЕЗЕНТАЦІЙНИХ УМІНЬ СПІВРОБІТНИКІВ ТУРИСТИЧНОЇ ГАЛУЗІ НА ЗАНЯТТЯХ ІЗ ІНОЗЕМНОЇ МОВИ
}

У статті визначено шляхи роботи над розвитком презентаційних умінь студентів спеціальності

'Туризм'. Відповідно до Типової програми англійської мови професійного спрямування встановлено комунікативні ситуації та функцї̈ монологічного мовлення в професійній площині; представлено функціональні зразки для опанування студентами на трьох етапах розвитку презентаційних умінь: рецептивно-репродуктивному, репродуктивно-продуктивному та творчому. Розроблено низку завдань для кожного етапу.

Ключові слова: презентаційні уміння, комунікативні функції презентації, професійна підготовка спеціалістів туристичної галузі, завдання для розвитку презентаційних умінь.

Постановка проблеми у загальному вигляді. Презентаційні вміння належать до загальнопрофесійних умінь, розвиток яких передбачений Типовою програмою англійської мови професійного спрямування, рекомендованою Міністерством освіти і науки України. Незалежно від спеціалізації, майбутні фахівці мають навчитися готувати та проводити презентації в своїй професійній площині. Актуальність розробки модуля, технології або серії завдань із розвитку презентаційних вмінь обумовлена відсутністю навчальних посібників, які задовольняють потреби студентів у розвитку презентаційних умінь з урахуванням професійних ситуацій конкретної галузі, незважаючи на детально визначені мікровміння та функціональні зразки, представлені у Типовій програмі.

Аналіз основних досліджень та публікацій. Питанням розвитку презентаційних умінь в сучасній науково-педагогічній літературі присвячені роботи Моркотуна С.Б., Казьмерчук А.В., Клименко А., Митник М. Проте недостатньо вивченим $є$ питання розвитку навичок іншомовного монологічного мовлення з урахуванням професійних ситуацій спілкування майбутніх спеціалістів туристичної галузі. Також існує потреба в розробці відповідного навчального модуля, інтегрованого до курсу іноземної мови професійного спрямування.

Отже, метою статті є уточнення особливостей професійно-орієнтованого монологічного мовлення спеціалістів туристичної галузі. 3 цією метою необхідно вирішити такі завдання: виділити основні професійні ситуації та функції монологічного мовлення в рамках презентації; адаптувати етапи навчання монологічного мовлення відповідно до вимог до розвитку презентаційних умінь; розробка алгоритму опанування презентаційних умінь співробітників туристичної галузі на заняттях 3 англійської мови в рамках окремого спеціалізованого навчального модуля.

Виклад основного матеріалу. Монологічне мовлення - зв'язне неперервне висловлення думок, спрямоване на одну людину або аудиторію з метою реалізації запланованого впливу. Для фахівців туристичної галузі комунікативна функція монологу-презентації залежить від професійної ситуації та мети висловлювання.

Проаналізувавши великий масив презентацій співробітників туристичної галузі, ми виділили основні професійні ситуації та, відповідно, комунікативні функції монологічного мовлення для подальшого формування презентаційних умінь, які загалом поділяються на інформативну, впливову, експресивну, розважальну та ритуально-культову функції [1: 167].

1. Науково-дослідна діяльність фахівців туристичної галузі передбачає презентацію результатів досліджень з різних аспектів туристичної індустрії на спеціалізованих конференціях та самітах. Основними комунікативними функціями монологічного мовлення в рамках таких презентацій $\epsilon$ інформативна та впливова.

Ми визначили найбільш популярну тематику досліджень на підставі програм конференцій туристичної індустрії, які відбулися у 2016-2017 роках: освіта та HR в галузі туризму; сільський туризм; культурна спадщина, культура та суспільство; маркетинг туристичних напрямів та маршрутів; туристичний досвід; сталий розвиток та туризм; події та фестивалі. 
Презентація результатів наукових досліджень передбачає, серед іншого, вміння коментувати графіки, таблиці, діаграми; інформувати про кількісні та якісні показники дослідження; чітко та логічно викладати гіпотезу дослідження та аргументацію; ставити риторичні питання до аудиторії; шанобливо висловлювати погодження або непогодження із аргументацією інших; дякувати за поставлені питання тощо. Загальні мовленнєві функції та зразки, які належать до групи презентаційних умінь, детально розглянуті в Типовій програмі англійської мови професійного спрямування (2005 рік) [2: 41$]$.

2. Робоче середовище фахівця туристичної галузі передбачає спілкування в рамках реалізації проектної діяльності, зокрема, презентацію звітів про реалізовані проекти. Метою монологічного висловлювання в контексті вищезазначеної професійної ситуації $є$ інформування та мотивація (інформативна та впливова функції монологу). Послідовне та логічне викладення даних про результати діяльності передбачає володіння лексикою, яка вживається в корпоративному середовищі та пов'язана 3 етапами реалізації проектної діяльності, розподілом обов'язків, встановленням графіку виконання дій, мотивацією співробітників та членів проектної команди.

3. Реклама, промо-діяльність в сфері туризму передбачає вміння презентувати компанію та

конкретний туристичний продукт. Серед функцій монологічного висловлювання в цьому контексті переважну значущість мають впливова, розважальна та експресивна, що значно впливає на вибір лексичного матеріалу та синтаксичної будови речень, зокрема, вживання емоційно виразної лексика, звернення до слухачів, вибір коротких та еліптичних речень тощо.

Визначивши основні професійні ситуації, які вимагають розвинутих презентаційних вмінь, проаналізуємо етапи розвитку навичок монологічного мовлення, адаптуючи їх до розвитку навичок презентації.

Ми виділяємо три етапи навчання монологічного мовлення в контексті набуття навичок презентації: рецептивно-репродуктивний, репродуктивно-продуктивний та продуктивний етап.

При володінні іноземною мовою на рівні В1 навчання монологічного мовлення в професійних ситуаціях спілкування зосереджується здебільшого на забезпеченні композиційно-смислової єдності тексту як продукту говоріння та оволодінні конкретними засобами міжфразового зв'язку, необхідними для успішної презентації матеріалу.

В першу чергу, студенти мають ознайомитися з особливостями різних типів презентацій, навчитися збирати іншомовний матеріал для презентації, створювати презентації в спеціалізованих програмах (Power Point) та укладати коментарі до слайдів, коментувати графіки, таблиці та кількісні дані, визначити власні улюблені прийоми привертання та утримання уваги слухачів тощо. Це вимагає детального вивчення презентацій інших лекторів, запрошених спікерів тощо. Тому актуальним матеріалом на першому етапі розвитку презентаційних умінь ми вважаємо аудіо-та відео-презентації професіоналів туристичної галузі, які супроводжуються низкою вправ та завдань на опанування вищезазначених умінь.

На першому, рецептивно-репродуктивному, етапі студентам пропонується перегляд презентацій та низка завдань для ознайомлення зі структурою презентації, техніками привернення уваги слухачів, лексичним матеріалом для забезпечення єдності та послідовності монологу тощо.

3 метою забезпечення всебічного підходу до професійного розвитку студентів ми пропонуємо для перегляду презентації блогерів, професійних лекторів та реальних виступів на конференціях туристичної галузі світового масштабу, зокрема, такі:

Презентація блогера Jean Marc https://www.youtube.com/watch?v=mz3JwD2V13M.

Виступ Алекса Керр на конференції TEDx у Кіото на тему 'New life for old towns through sustainable tourism': https://www.youtube.com/watch?v=kLRanIhp2jg.

Презентація Дага Ланскі (Doug Lanski), лектора, автора численних книжок про туризм, редактора та гостя міжнародних конференцій туристичного напряму на тему 'How to Fix Travel': https://www.youtube.com/watch?v=sBaiRpIpPKQ.

Приклади завдань на ознайомлення із структурою та техніками презентації:

- Watch the presentation and define the target audience: gender, age, profession. Are they investors? Partners? Tourists? Who will benefit from the presentation?

The optimal recommended presentation follows the rules: 10 slides, 20 minutes, font 30 . Watch the presentation and see whether the rule has been observed. If not, comment on the presenter's choice.

- There are several ways of holding the audience's attention: rhetorical questions, story-telling, references to sources of authority, humor, and statistics. Watch the presentation and comment on tick off the techniques the presenter uses to keep the audience engaged. Do they work for you?

- Using diagrams, graphs and images. After watching the presentation, you will receive handouts with images, diagrams and graphs used by the presenter. Explain what they represent.

One of the techniques to introduce the presentation is Pitching. The algorithm is as follows: presenting the problem - suggesting the solution - introducing the way of solving the problem - presenting yourselves or 
your company. Watch the presentation and jot down how the presenter introduces: self / the topic of presentation.

Також студенти мають опанувати лексичний матеріал, специфічний для проведення презентацій, зокрема, фрази та вислови для вступу до презентації (привітання аудиторії, представлення себе, представлення теми презентації, обгрунтування теми презентації, огляд плану презентації), для структурування монологічного мовлення під час презентації (презентація аргументів, посилання на джерела та власні дослідження, посилання на візуальну інформацію в презентації, представлення точки зору, наголошення на важливих аспектах, аналіз аргументів, перехід до наступного етапу / пункту презентації, надання рекомендацій), фрази та вислови для підбиття підсумків (формулювання висновків, підсумок основних думок та аргументів, завершення презентації), а також фрази та вислови для роботи 3 питаннями аудиторії (пропозиція ставити питання лектору, відповіді на питання, реакція на складні питання тощо).

Приклади завдань на опанування лексичного матеріалу для проведення презентацій:

- Match the word combinations with parts of the presentation they will likely be used in:

Parts of the presentation: introduction, main part, conclusion, answering questions.

Functional exponents:

- Hello and welcome to the presentation about...

- This presentation focuses on the issue of...

- Recent research has shown that...

- Did you know that...?

- If you have any questions, please do not hesitate to ask;

- Now I'd like to focus on..

- If you look at this table...

○ Turning now to...

○ In conclusion...

○ etc.

- Jigsaw puzzle: студентам пропонується відновити текст презентації в правильному порядку із наданих викладачем уривків презентації.

- Close tests: студентам пропонується текст презентації, який вони мають зробити привабливим для слухачів та структурованим за допомогою функціональних зразків (див. вище).

- Here is a presentation phrasebook that you may find helpful when preparing for a presentation. Watch the presentation and tick of the words and phrases used by the presenter in order to:

○ Greet the audience;

- Introduce themselves;

- Give the topic of presentation;

- Justify the topic of presentation;

- Give the outline of the presentation;

Introduce the main point;

- Refer to research and useful sources;

- Refer to visual data;

- Present own point of view;

○ Analyze an argument;

- Emphasize an important point;

- Move to another main point;

o Make recommendations;

- Make conclusions;

- Summarize main points;

- Finish the presentation;

○ Ask for questions;

○ Answer questions;

○ Deal with difficult questions [3].

На репродуктивно-продуктивному етапі студенти мають відтворювати переглянуті або прослухані презентації з обов'язковою модифікацією, що передбачає певний рівень мовленнєвої творчості. Важливим також є забезпечення студентів мовленнєвими, візуальними опорами з метою зосередження на мовленнєвому, а не на змістовому наповненні презентацій.

Перспективним на цьому етапі ми вважаємо застосування опорних презентацій професіоналів галузі, які є доступними в мережі Інтернет у форматі Power Point. Так, наприклад, на вебсайті 'Colorado Governor's Tourism Conference' (http://www.coloradotourismconference.com/presentations) оприлюднені презентації конференції, яка відбулася в 2017 році. Серед тем, які розглядалися, є й такі, які $\epsilon$ надзвичайно актуальними для українських реалій туристичної індустрії. Перевагою матеріалів, 
розташованих на вебсайті, є те, що презентації містять велику кількість актуальних статистичних даних, проблемних питань та шляхів їх вирішення, і не супроводжуються виступом лекторів. Презентації представлені в форматі Power Point i є достатньо детальними як джерело інформації для відтворення власне текстового матеріалу з метою складання студентами монологічного висловлювання на відповідну тему. Завдання для опрацювання таких презентацій поділяються на два типи:

а) відтворення змісту оригінальної презентації із застосуванням функціональних мовленнєвих одиниць, характерних для монологічного мовлення в рамках презентації, опанованих на рецептивнорепродуктивному етапі; та

б) модифікація оригінальної презентації залежно від контексту, наприклад, на підставі статистичних даних, які стосуються України, власної області, міста тощо.

Приклади презентацій, які пропонуються студентам на репродуктивно-продуктивному етапі для відтворення та модифікації:

'Формування туристичного бренду в рамках обмеженого бюджету': http://www.coloradotourismconference.com/files/presentations/LowBudgetBranding.pdf.

'Проблеми міст, перевантажених

http://www.coloradotourismconference.com/files/presentations/IntroducingRegionalBranding.pdf.

'Розвиток в вризму непопулярних місцевостях': http://www.coloradotourismconference.com/files/presentations/IntroducingDestinationDevelopment.pdf.

На продуктивному етапі необхідно запропонувати студентам систему вправ 3 поступовим ускладненням завдань - від складання окремих частин презентацій до виступу 3 власною повномасштабною презентацією. Важливо правильно формулювати комунікативні завдання для опрацювання студентами матеріалу під час складання презентації. В завдання необхідно якомога детальніше зазначати професійний контекст: цільову аудиторію, мету презентації (отримання фінансування, залучення інвесторів, продаж туристичного продукту, створення інформаційного приводу тощо). Доцільним є надання іншим студентам певних ролей для прослуховування презентацій один одного, щоб заохотити до аудіювання, а також ознайомлення 3 типовими ситуаціями професійного характеру (прискіпливі питання, критика аудиторії, відволікання слухачів, грунтовні заперечення, робота 3 технічними засобами тощо).

Приклади завдань (із поступовим ускладненням):

- Перегляньте основну частину презентації. Складіть вступ / заключну частину до неї.

- Перегляньте вступ до презентації. Чи є він вдалим? Чи достатньо залучена аудиторія? Яку техніку Ви б використали, щоб представити тему? Розробіть власний вступ.

- Розробіть серію риторичних питань для використання у презентації на тему...

- Скористайтеся технікою 'Pitching', щоб представити проблему...

- Прокоментуйте графік, діаграму або малюнок в контексті теми вашої презентації.

- Зробіть вступ до своєї презентації (1 хвилина). Попросіть слухачів одним реченням пояснити, що ви пропонуєте їм.

Ролі студентів для максимально ефективного залучення до прослуховування презентацій один одного:

- $\quad$ Ви - інвестор, шукаєте найбільш перспективний проект для фінансування. Оцініть презентації та оберіть проект, який підтримаєте.

- $\quad$ Ви - журналіст, пишете статтю про розвиток туризму на тлі занепаду культури. Ставте критичні питання доповідачу.

- $\quad$ Ви - блогер, який шукає нову тему для сюжету. Оберіть найбільш цікаву для себе тему.

- $\quad$ Ви - туроператор, шукаєте керівника маркетингового відділу. Оберіть людину, чий виступ мав на вас найбільше враження.

Під час розробки власних повномасштабних презентацій студенти можуть скористатися безкоштовними шаблонами презентацій Power Point, адаптованими для туристичної галузі:

- $\quad$ http://free-best-powerpoint.blogspot.com/;

- $\quad$ https://www.slidesalad.com/product/morph-travel-free-download-powerpoint-templates-presentation/;

- $\quad$ https://www.slidesalad.com/product/simple-free-powerpoint-presentation-template/;

- $\quad$ https://poweredtemplate.com/02310/0/index.html.

3 метою оптимальної підготовки студентів до майбутньої професійної діяльності вони мають ознайомитися з різними режимами проведення презентацій:

Бліц-презентації (the lightning rounds): презентації тривають не більше 25 хвилин (15 хвилин - власне презентація, 10 хвилин - відповіді на питання) і проводяться для аудиторії не більше 10-15 людей. Після завершення часу група слухачів переходить до наступного столу, де прослуховують іншу презентацію. Одна людина представляє свою презентацію три-чотири рази для різних груп, таким чином отримуючи максимальний зворотний зв'язок. 
Традиційна презентація: лектор має паперовий варіант свого виступу та представляє результати своєї роботи. Тривалість - до 20 хвилин, 5-10 хвилин для відповідей на питання.

Презентація експертної групи (panel talk): кілька лекторів проводять спільну лекцію-семінар на певну тему. Тривалість - до 90 хвилин, питання можуть ставитися до будь-якого учасника. Необхідно організувати вступну та заключну частину.

Експертна лекція: презентація тривалістю до 45 хвилин, 10-15 хвилин для відповідей на питання. Експертна лекція є тривалішою за традиційну презентацію, оскільки лектор є досвідченим експертом і представляє результати власного грунтовного дослідження, 3 детальним розглядом методології, концепції, висновків.

Дебати: два або три учасники, які є представниками діаметрально протилежних точок зору, обмінюються думками на певну тему. Модератор ставить серію питань для регулювання перебігу дебатів. Тривалість - до 90 хвилин, з яких 45 хвилин (половина часу) призначено для відповідей на питання аудиторії.

Круглий стіл: групова дискусія тривалістю до 60 хвилин, яка проводиться за круглим столом. Кількість учасників - до 15 людей. Доповідач має підготувати вступну частину дискусії, низку питань для організації перебігу дискусії, а також підбити підсумки: нову інформацію, зворотний зв'язок тощо.

Стендова доповідь (poster session): тривалість - до 120 хвилин. Доповідачі роблять презентацію впродовж відведеного часу, проте стенди залишаються доступними впродовж усієї конференції, та оцінюються журі наприкінці заходу [4].

Висновки та перспективи подальшого дослідження. Запропоновано алгоритм розвитку презентаційних умінь майбутніх співробітників туристичної галузі на заняттях із англійської мови, який складається 3 трьох етапів: рецептивно-репродуктивного, репродуктивно-продуктивного та продуктивного етапів. Для кожного етапу запропоновано низку завдань, адаптованих до контексту майбутньої професійної комунікації студентів. На підставі запропонованого алгоритму надалі необхідно розробити та задокументувати модуль із розвитку навичок презентації, інтегрований до курсу іноземної мови професійного спрямування, з урахуванням рівня розвитку іншомовної комунікативної компетенції студентів, а також етапу їхньої фахової підготовки.

\section{СПИСОК ВИКОРИСТАНИХ ДЖЕРЕЛ ТА ЛІТЕРАТУРИ}

1. Методика навчання іноземних мов у середніх навчальних закладах : [підручник] / кол. авторів під кер. С. Ю. Ніколаєвої. - К. : Ленвіт, 1999. - 320 с.

2. Програма з англійської мови для професійного спілкування - National ESP Curriculum / [колектив авторів : Г. Є. Бакаєва, О.А. Борисенко, І. І. Зуєнок, В. О. Іваніщева та інші]. - К. : Ленвіт, 2005 - 119 с.

3. English for University.com. Presentation Phrasebook. Version 1.1. [Електронний pecypc] / English for University.com - Режим доступу до ресурсу : http://englishforuniversity.com.

4. CES SCE. Types of Presentations [Електронний ресурс] / CES SCE. - Режим доступу до ресурсу : http://c2016.evaluationcanada.ca/types-of-presentations/index.html.

\section{REFERENCES (TRANSLATED \& TRANSLITERATED)}

1. Metodyka navchannia inozemnykh mov u serednikh navchal'nykh zakladakh [The Methodology of Teaching Foreign Languages in Secondary School] : [pidruchnyk] / kol. avtoriv pid ker. S. Yu. Nikolaievoi. - K. : Lenvit, 1999. - $320 \mathrm{~s}$.

2. Prohrama $\mathrm{z}$ angliiskoi movy dlia profesiinoho spilkuvannia - National ESP Curriculum [The Program of English for Professional Purposes - National ESP Curriculum] / [kolektyv avtoriv: G. Ye. Bakaieva, O.A. Borysenko, I. I. Zuyenok, V. O. Ivanishcheva ta inshi]. - K. : Lenvit, 2005 - 119 s.

3. English for University.com. Presentation Phrasebook. Version 1.1. [Elektronnyi resurs] / English for University.com. - Rezhym dostupu : http://englishforuniversity.com.

4. CES SCE. Types of Presentations [Electronic resource] / CES SCE - Rezhym dostupu do resursu : http://c2016.evaluationcanada.ca/types-of-presentations/index.html.

Рыбак Т. Н., Лесь Т. В. Развитие презентационных умений сотрудников туристической отрасли на занятиях по иностранному языку.

В статье определены пути работы над развитием презентационных умений студентов специальности 'Туризм'. Согласно Типовой программе английского языка для профессиональных иелей установлень коммуникативные ситуации и функции монологической речи в профессиональной сфере; представлень функциональные образць для овладения студентами на трех этапах развития презентационных умений: рецептивно-репродуктивном, репродуктивно-продуктивном и творческом. Разработаны задания для каждого этапа.

Ключевые слова: презентационные умения, коммуникативные функции презентации, профессиональная подготовка специалистов туристической сферы, задания для развития презентационных умений. 


\section{Rybak T. M., Les T. V. Developing Presentation Skills of Future Tourism Specialists in the Foreign Language Classroom.}

Presentation skills belong to the general set of professional skills set forth by the National ELT Curriculum for Universities. Regardless of the specialization, the students will face the objective of preparing and conducting presentation in their professional domain. Therefore, the necessity arises to introduce the teaching module, an algorithm or a set of tasks that will satisfy the students' need to develop presentation skills in view of specific professional context.

The article is aimed at determining the peculiarities of professionally oriented monologues of tourism experts, as well as developing the algorithm of enhancing presentation skills of the respective professionals in the English classroom within a separate teaching module.

The suggested algorithm contains three stages: receptive-reproductive, reproductive-productive and productive. For each stage a set of tasks is developed, adjusted to the context of professional communication in the field of tourism. The teaching materials in the form of presentations are developed based on the actual slides posted online as a follow-up of specialized conferences and other events. The article elaborates on the most popular topics for presentations in the field. Since following the B1 level of English mastery teaching monologue for professional purposes is focused mainly on the composition and coherence of speech and mastering the specific functional exponents used in presentations, the tasks aim at building students' confidence and awareness of various presentation types, teaching them to collect materials for presentations, use PowerPoint presentation samples, compile facilitator notes to the slides, comment on the graphs, tables, diagrams, pictures and numerical data.

Key words: presentation skills, English for professional purposes, ELT for tourism professionals, tasks for developing presentation skills. 